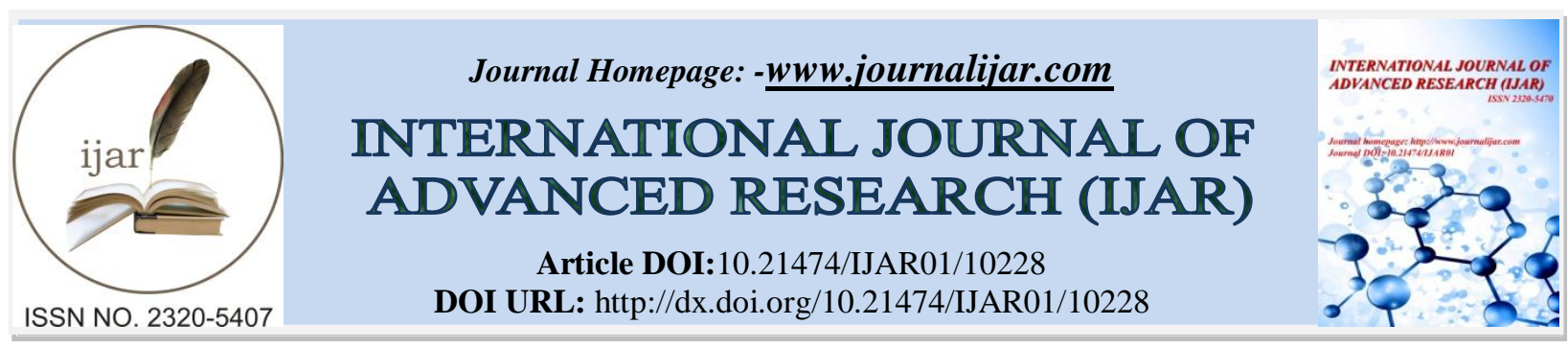

RESEARCH ARTICLE

\title{
THE PROCESS OF ORGANIZING ENVIRONMENTAL BASED ELECTIONS AT MANADO CITY
}

\author{
Herwyn Malonda ${ }^{1}$, Abdul Hakim ${ }^{2}$, Imam Hanafi ${ }^{2}$ and Bagyo Yanuwiadi ${ }^{2}$ \\ 1. Doctoral Program in Environmental Sciences, Brawijaya University. \\ 2. Lecturer Posgraduate Program Brawijaya University.
}

\section{Manuscript Info}

Manuscript History

Received: 10 October 2019

Final Accepted: 12 November 2019

Published: December 2019
Abstract

Society is the object and subject of development in relation to political aspects, the community itself is an important element in a country to build a democratic state. the community itself is an important institution in shaping "egality" in discourse and practice regarding everything related to social problems in general (Suparjan 2003). Community involvement is considered important in the implementation of elections. Society and the environment have an inseparable connection and are an important unity in everyday life. This study aims to find out and analyse the process of organizing environmental based elections at Manado City. The results of the study found that it is necessary to conduct a proper study and socialization and supervision of the election process, because it is difficult to change the public's view of the elections that are normally carried out with elections that will be based on electronic media. And the importance of environmental issues included in the election vision and mission is inseparable from the initial ways that can be done to realize environmental-based elections.

Copy Right, IJAR, 2019,. All rights reserved.

\section{Introduction:-}

Understanding of the election is very important because the election is a tool not an objective, the aim from the election implementation is to choose the right person to realize the mandate of the Act of 1945. The implementation of elections has an important meaning in supporting sustainable development and growth. The bottom line is that in its implementation to realize justice and prosperity, it is necessary to have a vision and mission that is proenvironment where the efforts to preserve the environment become a major part in sustainable development (Bahri and Mahpudi, 2017).

The focus on environmental issues in Indonesia is getting bigger, environmental damage caused by irresponsible exploitation is the main focus of the Indonesian government at this time. Environmental issues have become global issues worldwide. The Constitution in Indonesia expressly states that everyone has the right to a good and healthy environment and the human rights of their citizens. Indonesia's abundant natural wealth is wealth that must be protected in an integrated and integrated environmental management between the marine, land and air environments.

Environmental protection and management demands the development of an integrated system in the form of a national policy on environmental protection and management that must be carried out in a strict and consistent manner from the centre to the regions. The use of natural resources must be harmonious, harmonious, and balanced 
with environmental functions. As a consequence, development policies, plans and / or programs must be imbued with the obligation to conserve the environment and realize the goals of sustainable development (Wibawa, 2012).

The role of the KPU as a public service provider for elections has an important role in creating pro-environment elections. Not just pro-environment discourse but environmental issues should be the main theme in the election. For the sake of supporting concern for the environment of the democratic system and elections in Indonesia, it should prioritize the environment as the main focus in the holding of elections. The introduction of green constitution or known as green constitution is the application and implementation of environmental sovereignty or what is referred to as "ecocracy". The environment is not an object that can be carelessly exploited by humans, but rather on subjects who have their own rights to be preserved and protected. This concept first appeared in the fourth amendment of the 1945 Act of Indonesia (Asshiddiqie, 2009).

Elections are an important momentum in the election of both DPR (Indonesian Legislative Council) members, DPRD (Regional Legislative Council), PILKADA (Governor Election) until the Presidential election. Environmental issues have become an important issue raised in the campaign of each candidate. Start highlighting the use of attributes in elections that are not environmentally friendly can cause damage that will lead to ecological imbalances. As stated in KPU (General Election Commissions) regulation No. 7/2015 regarding the implementation of the campaign, the use and distribution of campaign props has been arranged (Prasetiyo, 2017).

Elections become an important event in this country, both in the election of the President, the elections, and the election of members of the DPR, DPRD, and DPD. Many things and issues that is coloured the election. The 10-fold increase in political party aid funds, the cost of holding elections, and the attributes of the campaign are much discussed. Pros and cons appear, election events cannot be separated from campaign attributes such as banners, leaflets, posters, T-shirts, pamphlets, brochures, and other advertising media. The facility is used to introduce candidates and programs offered. The scattering of campaign attributes often disturbs the comfort and beauty of the city. Installation of attributes in any place and the use of attribute materials that are not environmentally friendly become a classic problem in the election so far. that is at the time before, during, and after the campaign raises the problem of garbage attribute campaign.

Based on these problems, many studies are needed that reinforce the importance of general elections by evaluating studies in the form of models and programs that can be used as a basis for policy to formulate an environmentally friendly election mechanism. The most important thing is the use of Information and Communication Technology (ICT) is expected to provide a good effect in the new colour of democracy. It is believed that the pros and cons will definitely occur. Therefore the Electronic Election (e-voting) method requires preparation and improvement in order to meet the requirements to be used as a viable election method. It cannot be denied, people are becoming increasingly smart. Their boredom about voting methods is increasingly considered to be manipulated every day, making the presence of e-voting worthy of being a new method that deserves to be tested.

Based on the preliminary presentation it is deemed necessary to raise environmental issues as one of the important issues in organizing elections. The concept of pro-environment election can be an alternative in conducting elections in the city of Manado, the purpose of this study is to uncover and analyse the pro-environment election process in the city of Manado.

\section{Review of Literature:- \\ General Election Definition:-}

According to Act No. 7 of 2017 concerning General Elections for Members of the People's Legislative Assembly, Regional Representatives Council, and the Regional Legislative Council General Election is a tools of popular sovereignty to elect members of the House of Representatives, members of the Regional Representative Council, the President and Vice President, and to elect members of the House of Representatives Regions, which are carried out directly, generally, free, confidential, honest and fair in the Unitary State of the Republic of Indonesia based on the Pancasila and the Act of 1945 of the Republic of Indonesia. According to Ali Moertopo the understanding of the Election is as follows: "In essence, elections are a means available to the people to run their sovereignty in accordance with the written principle in the Opening of the Act of 1945. Election itself is basically a Democratic Institute that elects members of the people's representatives in the MPR, DPR, DPRD, who in turn are tasked with working together with the government, determining politics and running the state government". 
Many experts who explain the notion of elections, which stated by Ramlan Surbakti (1992: 181) Election is defined as a mechanism of selecting and delegating or handing over sovereignty to people or parties that are trusted, but the authors stipulate the notion of elections as stated in Law No. 7 of 2017 article 1 paragraph (1) referred to as General Election (Election) is a means of exercising people's sovereignty in the Unitary State of the Republic of Indonesia based on the Pancasila and the 1945 Constitution of the Republic of Indonesia.

The legal basis for conducting elections (KPU, 2016) is Law Number 7 of 1953 concerning the election of Constabulary Members Act Number 7 of 1953 concerning the election of Constituent Members and Members of Parliament as amended by Law Number 18 of 1953 Governmental Regulation Number 9 of 1954 concerning held the Election Law, Government Regulation Number 47 of 1954 concerning the Method of Nominating Membership of the DPR / Constituent Assembly by the Armed Forces Members and Statement of Non-Active / Dismissal based on the acceptance of the membership nomination membership, as well as the prohibition of holding an Election Campaign against Members of the Armed Forces.

The Election Campaign is carried out with the principle of joint learning and is responsible for the Election Campaign carried out by the campaign and supported by campaign officers which participated by campaign participants. The campaign organizer consists of the Political Party Board, candidates for DPR members, DPD, Provincial DPRD and Regency / City DPRD as well as campaigners and task forces. Participants in the campaign are voters, meanwhile campaign officers mean all officers who facilitate the implementation of the campaign (Act Number 1 of 2015 amended to Act Number 8 of 2015 and amended to Act Number 10 of 2016). Nurmardiansyah (2015) the green principle is commitment to the environment. This principle is part of a broader ideology that places human relations with nature as the main starting point. Where environmental certainty is a discourse as a process, not just the status of environmental awareness is important and urgent. This idea emerged as an execution in a state system that needs to prioritize the environment as the main objective, including in the implementation of democracy.

Green constitution is a state constitution that places environmental protection as an important consideration. This term was introduced by Jimmly Assidiqie, former Chair of the Constitutional Court. He mentioned that the substance of the green constitution was found in the fourth amendment of our Constitution, which was carried out in 2004. Unfortunately, this important change is rarely known to the public, because it is less socialized and less used in everyday policies. One of the ideas and developments in efforts to protect the environment is to place environmental rights in the country's constitution as a commitment to environmental protection and management. The Green Constitution is one of the things that responds to various kinds of community concerns regarding environmental degradation as stated: "This country is seeing an unstoppable process of ecological urgency, an ecological disaster threatening where millions of people continue to bet on the safety of themselves and their families they are due to the weak role of the state in protecting the safety of its citizens as mandated in the country's Constitution "(Jimly, 2009)

\section{Research Method:-}

This research was conducted using a research model with a qualitative approach that examines in depth a factual phenomenon based on information and facts that exist in a real event, accompanied by the involvement of other effects that support research. In essence, this research seeks to develop concepts and facts in depth to answer questions relating to the phenomenon of election problems that have occurred so far towards the basis of proenvironment elections. The study was conducted in the city of Manado.

Research data obtained from informants, documents, as well as places and events. Informants are people who are considered appropriate and can be trusted to provide data sources to reveal a phenomenon. Information gathering begins with the introduction of the initial informant who then appoints the main informant (key informant). Information from the main informant is then actualized and enriched in a rolling manner (snowballing) to the next informant until information saturation occurs. This is done so that the variation, depth, and detail of data / information can be obtained optimally. The main informants or key informants in this study are the Chairperson of the Provincial KPU, Academics and community activists who according to the initial informants or key informants are considered to know, master, and understand and even appreciate matters relating to the research problem.

\section{Research Result:-}

This research conducted interviews with several speakers who obtained the results that: 
1. The discourse on environmental based election is still a new thing that needs to be carried out with a more thorough assessment in the implementation of elections which up to now still uses the old traditional methods. Many aspects must be reviewed in implementing environmentally based elections that use a data base media and e-voting-based elections to reduce paper usage.

2. Evaluation of the election this far is still using the manual method deemed quite difficult and requires energy, time and relatively large costs. It is necessary to further examine the impact that will emerge if the election uses electronic media, especially in seeing electoral fraud and the mistakes that usually occur when elections are carried out manually.

3. The fact is the direct election policy whose ultimate goal is to elect the regional head and deputy regional head that so far has been carried out in Manado, which has not put environmental issues as the main issue. It can be said that the implementation of quality elections is still in the discourse that is being monitored during the elections in the city of Manado. In addition, another problem faced when the implementation of environmentbased elections is carried out is the need for rigorous and consistent evaluations given that the elections are still being evaluated with the existing shortcomings.

4. This condition does not rule out the possibility of enacting e-election based on electronic media to lead to a proliferation of elections, the inclusion of environmental issues in the vision and mission of election participants is a progress. However, the implementation in the city of Manado is still found in election practices that actually cannot be said to be pro-environment

\section{Conclusions and Suggestions:-}

In implementing environmentally based elections in the city of Manado, collaboration between all parties is needed in realizing it, so there is a need for better socialization in realizing this plan. The level of support and performance of the KPU is considered important in carrying out a pro-environment democratic party in the city of Manado.

So the suggestion that can be done is to start making rules and mechanisms for elections that are pro-environment, by giving post-supervisory authority in carrying out supervision of the course of the environment. Early socialization also needs to be done to the community to reduce the impact of community confusion with the e-voting discourse that they want to do.

\section{Bibliography:-}

1. A'an Effendi, Jurnal Perspektif Penyelesaian Sengketa Lingkungan Melalui Peradilan Tata Usaha Negara, Volume XVIII No. 1 Tahun 2013 Edisi Januari

2. Azahar Kasim et al. 2016. The 2013 general election in Malaysia: An analysis of online newa portal. Kasetsart Journal of Social Sciences 37 (2016) 119-125

3. Bahri, Syamsul dan Mahpudi. 2017. PemiludanLingkunganhidup. http://kerincitime.co.id/pemilu-danlingkungan-hidup-syamsul-bahri-se-dan-mahpudi-sh.html, diaksespada 22 Februari 2018.

4. Bodet, Marc Andre et al. 2016. Come hell or high water: An investigation of the effects of naturan disaster on local election. Journal of Electoral Studies 43 (2016) 85-94

5. Davis, Charles. 2016. Fracking and Enviromental Protection: An Analysis of U.S State policies. Journal The Extractive Industries and Society xxx (2016) xxx.

6. Daly, Erin. 2012. Constitutional Protection for Enviromental Right: The Benefits of Environmental Process. International Journal of Peace Studies, Volume 17, Number 2 Winter 2012.

7. Fankhauser, Sam et al. 2015. The political economy of passing climate change legislation: Evidence from a survey. Journal of Global Environment Change 35 (2015) 52-61

8. Frances Millard. 2011. Electoral-system change in Latvia and the elections of 2010. Communist and Postcommunist Studies 44 (2011) 309-318

9. Gabriella Ilonszki et al. 2016. Parliamentary elections in Hungary, 2014. Journal Electoral Studies xxx 92016) $1-4$

10. Hammam, Riza, A. Grahitandaru, B. Prasetyo, S. Saraswati W.W., F. Ba’abdullah, K. Supriatna, A. Santosa, Samargi, F. Ayuningtyas, dan M.D. Wahyu, "PengembanganStandarKeamananBagiAplikasidanSistem EVoting Nasional," PusatTeknologilnformasidanKomunikasi, BPPT, Jakarta, 2012.

11. McCright, Aaron M. 2014. Political polarizarion on support for government spending on environmental protection in the USA, 1974-2012. Journal of Social Science Research 48 (2014) 251-261

12. Norris, Pipa. 2013. The new research agenda study electoral integrity. Journal Electoral Studies 32 (2013); 563 575 
13. Pan Mohamad Faiz,2016,Jurnal Konstitusi, Volume 13, Nomor 4, Desember 2016

14. Parola, Giulia. 2009. Toward Environmental Democracy. Thesis: Faculty of Law, University of Iceland

15. Prasetiyo, KurniaWiji. 2017. Pemilu Ramah Lingkungan. www.mediaindonesia.com diakses pada 22 Februari 2018.

16. TaufiqurrohmanSyahuri, 2011, TafsirKonstitusiBerbagaiAspekHukum, Jakarta, Prenada Media Group, hlm 156.

17. (Tanpa SekretariatjenderaldanKepaniteraanMahkamahKonstitusi, Jakarta.

18. Santosa, Mas Achmad. 2001. "PeranReformasiHukumdalamMewujudkan Good Environmental Governance," Good Governance danHukumLingkungan. Jakarta: ICEL.

19. Saiful, Anwar, Sendi-sendiHukum Tata Negara Indonesia (Era Reformasi), Gelora Madani Press, Medan, 2004.

20. Soerjono Soekanto Pengantar Penelitian Hukum, UI Press, Jakarta, 1986.

21. --------- dan Sri Mamudji, Penelitian Hukum Normatif Satu Tinjauan Singkat, CV Rajawali, Jakarta, 1985 Pengantar Penelitian Hukum, UI Press, Jakarta, 1986.

22. Tim Penyusun Naskah Komprehensif Proses dan Hasil Perubahan UUD 1945, 2008, Naskah Komprehensif Perubahan Undang-Undang Dasar 1945; Buku V tentang Pemilihan Umum, Sekretariat Jenderal dan Kepaniteraan Mahkamah Konstitusi, Jakarta

23. Wibawa,IPutuSastra.2016.PolitikHukumPerlindungandanPengelolaanLingkunganHidupMenujuEkokrasi di Indonesia. KanunJurnalIImuHukum Vol. 18, No. 1; 51-68

24. WijoyoSuparto.2009. KonstitusionalitasHakAtasLingkungan. Surabaya: Airlangga University Press. 